\title{
PELATIHAN PENYUSUNAN PROPOSAL PENELITIAN TINDAKAN KELAS BAGI GURU DI TAMAN KANAK-KANAK AL-JUNDI KOTA BENGKULU
}

\author{
Training for The Preparation of Classroom Action Research Proposals for Teachers in \\ Kindergarten Al Jundi, Bengkulu City \\ ${ }^{1)}$ Nasirun, ${ }^{2)}$ Yulidesni, ${ }^{3)}$ Indrawati, ${ }^{4}$ Zahratul Qalbi \\ Fakultas Keguruan dan Ilmu Pendidikan, Universitas Bengkulu. \\ *Email: zahratulqalbi@unib.ac.id
}

\begin{abstract}
ABSTRAK
Pengabdian ini dilatarbelakangi oleh rendahnya keterampilan guru TK dalam menyusun proposal penelitian tindakan kelas. Tujuan kegiatan pengabdian ini adalah untuk meningkatkan kemampuan guru TK Al-Jundi Kota Bengkulu dalam penyusunan proposal penelitian tindakan kelas. Khalayak sasaran dalam kegiatan pengabdian ini adalah seluruh guru TK Al-Jundi Kota Bengkulu dan guru PAUD di sekitar yang berjumlah 11 orang guru. Metode pada kegiatan pengabdian ini adalah ceramah dan tanya jawab (orientasi), dilanjutkan dengan penugasan (latihan) menyusun proposal penelitian tindakan kelas secara garis besarnya (belum detail dan rinci) di PAUD masing-masing. Hasil pengabdian berupa pengetahuan tentang penelitian tindakan kelas dan bagaimana penyusunan proposal penelitian tindakan kelas yang kemudian dikonsultasikan secara individu. Diharapkan setelah kegiatan pelatihan penyusunan proposal penelitian tindakan kelas hendaknya dapat ditindaklanjuti dengan bimbingan dosen PAUD FKIP Universitas Bengkulu, karena sangat membantu guru dalam rangka kenaikan pangkatnya.
\end{abstract}

Kata Kunci: Penelitian Tindakan Kelas, Guru Taman Kanak-Kanak

\begin{abstract}
This dedication was motivated by the low skills of kindergarten teachers in preparing classroom action research proposals. The purpose of this service activity is to improve the ability of TK Al-Jundi Kindergarten teachers in Bengkulu City in preparing classroom action research proposals. The target audience in this service activity is all teachers of Kindergarten Al-Jundi in Bengkulu City and PAUD teachers around, totaling 11 teachers. The method in this service activity is lectures and questions and answers (orientation), followed by assignments (exercises) to compile a classroom action research proposal in outline (not yet detailed and detailed) in each $P A U D$. The results of the service are in the form of knowledge about classroom action research and how to compile a classroom action research proposal which is then individually consulted. It is hoped that after the training activities, the preparation of classroom action research proposals should be followed up with the guidance of PAUD FKIP Bengkulu University lecturers, because it is very helpful for teachers in the context of promotion.
\end{abstract}

Keywords: Classroom Action Research, Kindergarten Teachers

Diterima : 12-11-2020 Disetujui : 20-12-2020 Dipublikasikan : 30-12-2020 


\section{PENDAHULUAN}

Undang-undang Nomor 14 Tahun 2005, tentang: Guru dan Dosen, Pada pasal 8 disebutkan: Guru wajib memiliki kualifikasi akademik, kompetensi, sertifikat pendidik, sehat jasmani dan rohani, serta memiliki kemampuan untuk mewujudkan tujuan pendidikan nasional. Pada pasal 10 ayat 1 , menyebutkan bahwa: Kompetensi guru sebagaimana dimaksud dalam Pasal 8 meliputi kompetensi pedagogik, kompetensi kepribadian, kompetensi sosial, dan kompetensi profesional yang diperoleh melalui pendidikan profesi. Pada ayat 2, menyebutkan bahwa: Ketentuan lebih lanjut mengenai kompetensi guru sebagaimana dimaksud pada ayat (1) diatur dengan Peraturan Pemerintah.

Pada Peraturan Menteri Pendidikan dan Kebudayaan No. 137, tahun 2014; tentang Standar Pendidikan Anak Usia Dini (PAUD), tertuang dalam standar pendidikan dan tenaga kependidikan menyebutkan bahwa guru pada kompetensi Paedagogik butir K menyebutkan bahwa guru harus melakukan tindakan reflektif, korektif dan inovatif dalam meningkatkan kualitas proses dan hasil pengembangan anak usia dini. Kompetensi tersebut dapat dilakukan dengan cara sebagai berikut: 1. Melakukan refleksi terhadap kegiatan pengembangan anak usia dini yang telah dilaksanakan 2. Meningkatkan kualitas pengembangan anak usia dini melalui penelitian tindakan kelas 3. Melakukan penelitian tindakan kelas.

Pada kenyataan di lapangan pelaksanaan butir ketiga yaitu kegiatan melakukan penelitian tindakan kelas sangat jarang dilakukan oleh para guru di PAUD. Hal tersebut disebabkan kurang mampunya para guru dalam memahami maupun melakukan penelitian tindakan kelas (PTK) tersebut. Pada sisi lain bagi guru yang berstatus pegawai negeri sipil (PNS) setiap kenaikan pangkat diwajibkan untuk melampirkan laporan hasil penelitian tindakan kelas (PTK), sebagai bagian dari kegiatan refleksi atau perbaikan dalam proses pengajaran yang dilakukan oleh guru. Sebagai akibatnya, pada akhirnya banyak para guru yang terhenti atau tidak naik pangkat.
Sebagai kompetensi yang harus dikuasai dan dijalankan guru harus dituntut untuk melakukan kegiatan penelitian tindakan kelas (PTK) sebagai bagian kewajiban dari kompetensi yang harus dikuasai oleh guru, sebagaimana diwajibkan dalam undangundang tersebut diatas (UU No. 14 tahun 2005 tentang Guru dan Dosen serta Permendikbud. Nomor 137 Tahun 2014 tentang Standar Nasional Pendidikan Anak Usia Dini).

Permasalahan yang muncul adalah semakin banyak guru-guru Pendidikan Anak Usia Dini (PAUD) yang tidak bisa naik pangkat. Dalam rangka mengatasi permasalah tersebut, maka perlu adanya kegiatan untuk membekali kemampuan dalam penyusunan proposal penelitian tindakan kelas (PTK). Yang pada akhirnya diharapkan para guru dapat melaksanakan penelitian tindakan kelas (PTK) setelah diberikan pelatihan dalam penyusunan proposal penelitian tindakan kelas tersebut.

Aqib (2006, 12) menyebutkan bahwa Penelitian Tindakan Kelas (PTK) yang dalam bahasa Inggrisnya "Classroom Action Research" merupakan bagian dari penelitian tindakan (action research). Lewin (1946) dalam Aqib (2006, 13) mengembangkan penelitian tindakan atau "Action Research" yaitu: suatu rangkaian langkah yang terdiri atas empat tahap (perencanaan, tindakan, pengamatan dan refleksi). Kemudian dari jenis penelitian "Action Research" diterapkan dalam pengembangan dan perbaikan dalam kelas yang disebut "Classroom Action Research" (CAR). Jadi "Classroom Action Research" merupakan bentuk kegiatan penelitian dalam rangkan perbaikan atau refleksi guru dalam pembelajaran untuk memperbaiki rasionalitas dan keadilan (praktik pembelajaran; pemahaman pembelajaran; situasi dalam pelaksanaan).

Penelitian Tindakan Kelas merupakan suatu kegiatan penelitianyang dilakukan oleh pendidik untuk memperbaiki kinerja mengajar atau proses pembelajarannya menurut Nasirun (2017). Penelitian Tindakan Kelas berguna dalam rangka meningkatkan profesionalisme guru dalam melaksanakan profesinya. Selain itu, Penelitian Tindakan Kelas membuat guru menjadi lebih peka dan tanggap terhadap 
dinamika pembelajaran di kelasnya. Guru tidak hanya menjadi praktisi yang merasa puas terhadap apa yang selama ini dikerjakan bertahun-tahun tanpa upaya perbaikan dan inovasi, namun dengan kegiatan Penelitian Tindakan Kelas lebih bisa melaksanakan perbaikan dan inovasi dalam pelaksanaan proses pembelajarannya. Guru bisa melakukan perbaikan proses pembelajarannya melalui kajian-kajian ilmiah dan selalu melaksanakan adaptasi-adaptasi terhadap perkembangan proses pembelajaran.

Pada sisi lain Arikunto (2007) dalam Asrori $(2009$; 28-30) mengemukakan adanya sejumlah prinsip-prinsip atau asas-asas dalam Penelitian Tindakan Kelas yang dilakukan oleh guru, diantaranya: (1) Azas Kegiatan Nyata dalam Situasi Rutin PTK, hendaknya dilakukan tanpa mengubah situasi rutin sebagaimana aslinya. Jika penelitian tindakan kelas dilakukan dalam situasi yang berbeda, maka hasilnya tidak bisa dijamin dapat diterapkan lagi dalam situasi yang sama. Sebab, hasil penelitian yang tidak diperoleh dari situasi rutin akan menjadi tidak wajar atau tidak alami. Oleh karena itu, penelitian tindakan kelas tidak perlu diadakan atau dilaksanakan dalam waktu khusus, tidak perlu mengubah jadwal pembelajaran yang sudah ada, melainkan melebur dengan kegiatan pembelajaran yang sesuai dengan jadwal yang ada secara apa adanya.

Winter (1999) mengemukakan enam azas yang mendasari pelaksanaan penelitian tindakan kelas, yaitu azas kritik reflektif, azas kritik dialektis, azas sumber daya kolaboratif, azas resiko, azas struktur majemuk, dan azas teori praktek dan transformasi. Sementara Winter (1999) dalam Asrori (2009;31-38) menyatakan bahwa ada enam asas yang mendasari pelaksanaan penelitian tindakan kelas, yaitu: (1) Asas kritik reflektif; (2) Asas kritik dialektis; (3) Asas sumber daya kolaboratif; (4) Asas resiko; (5) Asas struktur majemuk; (6) Asas teori-praktek-transformasi. Menurut Hopkins (1993), dalam Aqib (2006, 17), menyebutkan prinsip-prinsip dalam pelaksanaan Penelitian Tindakan Kelas yaitu sebagai berikut: (1) Pekerjaan utama guru adalah mengajar, adapun metode PTK yang diterapkannya seyogianya tidak mengganggu komitmennya sebagai pengajar; (2) Metode pengumpulan data yang digunakan tidak menuntut waktu yang berlebihan dari guru sehingga berpeluang mengganggu proses pembelajaran; (3) Metode yang digunakan harus reliable, sehingga memungkinkan guru mengidentifikasi serta merumuskan hipotesis secara meyakinkan, mengembangkan strategi yang dapat diterapkan pada situasi kelasnya, serta memperoleh data yang dapat digunakan untuk menjawab hipotesis yang dikemukakannya; (4) Masalah program yang diusahakan oleh guru seharusnya merupakan masalah yang cukup merisaukan, dan bertolak dari tanggung jawab profesional; (5) Dalam menyelenggarakan PTK, guru harus selalu bersikap konsisten menaruh kepedulian tinggi terhadap proses dan prosedur yang berkaitan dengan pekerjaannya; (6) Dalam pelaksanaan PTK sejauh mungkin harus digunakan class room excerding perspective, dalam arti permasalahan tidak dilihat terbatas dalam konteks kelas dan atau mata pembelajaran tertentu, melainkan perspektif misi sekolah secara keseluruhan. Sebagai contoh yang dilakukan oleh Kepala sekolah. Sekolah adalah memperbaiki sekolah, sedangkan Pengawas sekolah memperbaiki sistem pendidikan (operasional kepengawasan).

PTK hanyalah sebuah model yang penting proses memperbaiki. Menurut Hopkins (1993), dalam Arikunto (2010, 115), menyebutkan prinsip dasar yang melandasi pelaksanaan Penelitian Tindakan Kelas yaitu sebagai berikut: (1) Tugas pendidik dan tenaga kependidikan yang utama adalah menyelenggarakan pembelajaran yang baik dan berkualitas, untuk itu perlu komitmen dalam mengupayakan perbaikan dan peningkatan kualitas pembelajaran secara terus menerus. Jika dalam menerapkan suatu tindakan yang dipilih tidak/kurang berhasil maka ia harus tetap berusaha mencari alternatif lain. Prinsip utama ini berimplikasi pada sifat penelitian tindakan sebagai suatu cara berkelanjutan secara siklus sampai terjadinya peningkatan, atau "kesembuhan" sistem, proses, hasil dan sebagainya; (2) Meneliti merupakan bagian intergral dari pembelajaran, yang tidak menuntut kekhususan waktu maupun metode pengumpulan data. Tahapan penelitian tindakan selaras dengan pelaksanaan 
pembelajaran, yaitu persiapan program (planning), pelaksanaan pembelajaran (action, observasi kegiatan pembelajaran (observation), evaluasi terhadap kegiatan/proses dan hasil pembelajaran (reflection). Prinsip kedua ini mengisyaratkan agar proses dan hasil pembelajaran direkam dan dilaporkan secara sistematik ddan terkendali menurut kaidah ilmiah; (3) Kegiatan meneliti, yang merupakan bagian integral dari pembelajaran harus diselenggarakan dengan tepat bersandar padaalur dan kaidah ilmiah. Alur pikir yang digunakan dimulai dari masalah, pemilihan tindakan yang sesuai dengan permasalahan dan penyebabnya, merumuskan hipotesis tindakan yang tepat, penetapan skenario tindakan, penetapan prosedur pengumpulan data dan analisis data. Objektivitas, reliabilitas, dan validitas proses, data, dan hasil tetap dipertahankan selama penelitian berlangsung. Prisip kegiatan ini mempersyaratkan bahwa dalam menyelenggarakan penelitian tindakan agar tepat menggunakan kaidah-kaidah ilmiah; (4) Masalah yang ditangani adalah masalahmasalah pembelajaran yang riil merisaukan tanggung jawab profesional dan komitmen terhadap diagnosis masalah bersandar pada kejadian nyata yang berlangsung dalam konteks pembelajaran yang sesungguhnya. Apabila pendiagnosisan masalah berdasarkan pada kajian literatur semata, maka penelitian tersebut dipandang sudah melanggar prinsip keotentikan masalah. Jadi, maalah harus didiagnosis dari kancah pembelajaran yang sesungguhnya, bukan sesuatu yang dibayangkan akan terjadi secara akademik; (5) Konsistensi sikap dan kepedulian dalam memperbaiki dan meningkatkan kualitas pembelajaran tidak dapat dilakukan sambil lalu, tetapi menuntut perencanaan dan pelaksanaan yang sungguh-sungguh. Oleh karena itu, motivasi untuk memperbaiki kualitas harus tumbuh dari dalam (motivasi intrinsik), bukan sesuatu yang bersifat instrumental; (6) Cakupan permasalah penelitian tindakan tidak seharusnya dibatasi pada masalah pembelajaran di kelas, tetapi dapat diperluas pada tataran di luar kelas, misalnya tataran sistem atau lembaga.

Perspektif yang lebih luas akan memberi sumbangan lebih signifikan terhadap upaya peningkatan kualitas pendidikan. Jadi pentingnya Penelitian Tindakan Kelas bagi guru adalah: (1) guru peka dan tanggap terhadap dinamika pembelajaran; (2) adanya peningkatan kinerja guru dalam proses pembelajaran; (3) adanya perbaikan proses belajar mengajar melalui kajian; (4) Penelitian Tindakan Kelas tidak ganggu tugas guru (5) guru menjadi lebih kreatif; dan (6) pengajaran yang dilakukan guru lebih reflektif.

Langkah-langkah praktis dalam Penelitian Tindakan Kelas menurut Asrori, dkk. (2009;116-122) diantaranya:

Perencanaan; diantaranya:

Mengidentifikasi dan menganalisis masalah; (b) Rumusan Masalah; (c) Hipotesis Tindakan; (d) Pelaksanaan atau Tindakan; (e) Observasi atau pengamatan; (f) Refleksi. Sementara dalam kegiatan refleksi meliputi; (a) Olah Data dan Menafsirkan; (b) Analisis Data; (c) Validasi Data dan Kredibilitas Penelitian; (d) Laporan Hasil Penelitian.

Tujuan yang diharapkan dan akan dicapai dalam kegiatan pengabdian pada masyarakat melalui pelatihan penyusunan proposal ini adalah: Diharapkan ada peningkatan kemampuan guru-guru TK AlJundi Kota Bengkulu dalam penyusunan proposal Penelitian Tindakan Kelas (PTK), selanjutnya pelaksanaan tindakan kelas dan penyusunan laporan sehingga dapat dipergunakan dalam kenaikan pangkat.

\section{METODE}

Metode kegiatan pengabdian dalam masyarakat ini dilakukan: pertama, orientasi dengan ceramah dan tanya-jawab, selanjutnya diteruskan dengan penugasan membuat secara garis besar penyusunan proposal penelitian tindakan kelas di sekolah masing-masing.

Khalayak sasaran kegiatan pengabdian kepad a masyarakat ini diikuti oleh seluruh guru TK Al-Jundi Kota Bengkulu berjumlah 11 orang.

\section{HASIL DAN PEMBAHASAN}

Kegiatan Orientasi, kegiatan pengabdian pada masyarakat ini diawali dengan memberikan orientasi dan tanya jawab tentang PTK. Kegiatan orientasi dilakukan dengan penyampaian materi yang meliputi: Penjelasan tentang Pengertian PTK; Pentingnya PTK; Kelebihan dan kelemahan PTK; Langkah-langkah PTK; Penyusunan 
Proposal PTK; dan Penyusunan laporan PTK. Setelah dilaksanakan orientasi dilanjutkan dengan tanya jawab seputar Penelitian Tindakan Kelas (PTK); Hal yang dapat ditarik kesimpulan dari orientasi dan tanya jawab, diantaranya: (1) Belum sepenuhnya para guru memahami PTK; (2) Penyusunan proposal PTK; (3) Penyusunan Laporan PTK;

Sebagai kesimpulan dari kegiatan orientasi, masih perlu memberikan materi berkaitan dengan Penelitian Tindakan Kelas (PTK); dan Penyusunan proposal dan laporan Penelitian Tindakan Kelas (PTK);. Kegiatan orientasi diikuti oleh sembilan orang guru TK Al-Jundi Kota Bengkulu.

Hasil Kegiatan, setelah dilaksanakan kegiatan orientasi, selanjutnya dilaksanakan pelatihan penyusunan proposal penelitian tindakan kelas (PTK). Kegiatan yang dilakukan: pertama: mencari dan menemukan permasalahan yang ada di kelas masingmasing. Guru berdiskusi dan menyimpulkan permasalahan yang mendasar dan perlu adanya penyelesaian permasalahan tersebut, sebab bila dibiarkan akan mengganggu proses belajar berkelanjutan. kedua: setelah menemukan permasalah yang utama yang harus segera mendapat perhatian untuk penyelesaian, dilanjutkan membuat rancangan penyelesaian masalah yang dihadapi melalui penelitian tindakan kelas, sekaligus merancang judul PTK-nya. ketiga: menyusun latar belakang secara garis besar, kemudian dilanjutkan dengan merumuskan masalah, merumuskan tujuan dan manfaat yang diharapkan dari penelitian tindakan kelas. keempat: merancang garis besar tentang kajian teori yang akan dijadikan landasan penelitian sesuai judul yang dibuat oleh para guru/peserta pelatihan. kelima: menyusun metode penelitian, meliputi membuat garis besar rancangan atau langkahlangkah persiapan dalam PTK, dilanjutkan menyusun rancangan pelaksanaannya, caracara melaksanakan pengamatan atau observasi dan bagaimana melakukan pengolahan data yang sudah dikumpulkan.

Pembahasan Hasil, dari pelaksaan kegiatan pengabdian pada masyarakat ini dapat ditemukan beberapa hal, diantaranya: (a) Pemahaman para guru tentang penelitian tindakan kelas dan pentingnya bagi guru melakukan refleksi melakukan perbaikan dengan jalan penelitian tindakan kelas belum sepenuhnya memahami ; (b) Pemahaman mengenai penyusunan proposal penelitian tindakan kelas serta langkah-langkah yang harus dilakukan dalam penyusunan proposal penelitian tindakan kelas belum dipahami secara menyeluruh; (c) Sebagai akibatnya banyak para guru yang tidak bisa naik pangkat, disebabkan persyaratannya harus menggunakan penelitian tindakan kelas yang sudah diseminarkan selalu mengalami kendala. (d) Para guru kesulitan dalam melaksanakan penelitian tindakan kelas (PTK) karena kurang paham dalam alur penyusunan proposal PTK dan permasalahan legalitas hasilnya. Diharapkan item (d) selanjutnya dapat ditindaklanjuti pada kegiatan pembimbingan pelaksanaan tindakan kelas melalui kerjasama para dosen PAUD sebagai tim pengebdian dengan para guru TK Al-Jundi Kota Bengkulu dalam melaksanakan tindakan kelas dan seminar hasil penelitian tindakan kelas tersebut. Dengan demikian, diharapkan kedepan para guru memiliki mitra dalam rangka memfasilitasi dalam mengusulkan kenaikan pangkatnya.

\section{SIMPULAN}

Setelah dilaksanakan kegiatan pengabdian pada masyarakat yang berupa Pelatihan Penyusunan Proposal Penelitian Tindakan Kelas (PTK) di TK Al-Jundi Kota Bengkulu, serta dilakukan evaluasi atau umpan balik, maka dapat disimpulkan bahwa terjadinya peningkatan keterampilan dalam penyusunan proposal penelitian tindakan kelas. Tindakan berikutnya sebagai tindak lanjut kegiatan para guru menyusun proposal di masing-masing sekolah.

\section{DAFTAR PUSTAKA}

Aqib, Zainal, 2009. Penelitian Tindakan Kelas, untuk Guru; Bandung: Yrama Widya.

Arikunto, Suharsimi, dkk. 2010. Penelitian Tindakan Kelas. Jakarta: Bumi Aksara.

Asrori; Mansyur dan Harun Rasyid; (2009); Penelitian Tindakan Kelas; Peningkatan Kompetensi Profesional Guru; Multi Presindo; Yogyakarta.

Pedoman Kurikulum Pendidikan Anak Usia Dini 2013 
Nasirun, Yulidesni, Indrawati, Zahratul Qalbi

Pelatihan Penyusunan Proposal Penelitian Tindakan Kelas....

Moeslichatun, R.; (2004); Metode Pengajaran di Taman Kanak-Kanak; Rineka Cipta, Jakarta.

Nasirun,M dan Yulidesni (2017), (Pengebadian pada Masyarakat) Pelatihan Penyusunan RPPH pada guru TK Dharmawanita Propinsi Bengkulu.

Nasirun,M dan Yulidesni (2016), (Pengebadian pada Masyarakat) Pelatihan Penyusunan RPPH pada guru PAUD Pertiwi I Kota Bengkulu.

Nasirun,M dan Yulidesni (2017), (Pengebadian pada Masyarakat) Pelatihan Penyusunan RPPH pada guru TK Kartika dan Al-Jundi Kota Bengkulu.

Peraturan Pemerintah Nomor 19 Tahun 2005. tentang Standar Nasional Pendidikan, Jakarta.

Permendikbud. Nomor 137 Tahun 2014 Tentang Standar Nasional Pendidikan Anak Usia Dini, Depdikbud, Jakarta.

Permendikbud. Nomor 146 Tahun 2015 Tentang Pelaksanaan Kurikulum 2013 Pendidikan Anak Usia Dini, Depdikbud, Jakarta.

Undang-Undang Nomor 20 tahun 2003; tentang Sistem Pendidikan Nasional, Jakarta .

Undang-Undang Nomor 14 Tahun 2005

Tentang Guru dan Dosen, Jakarta 